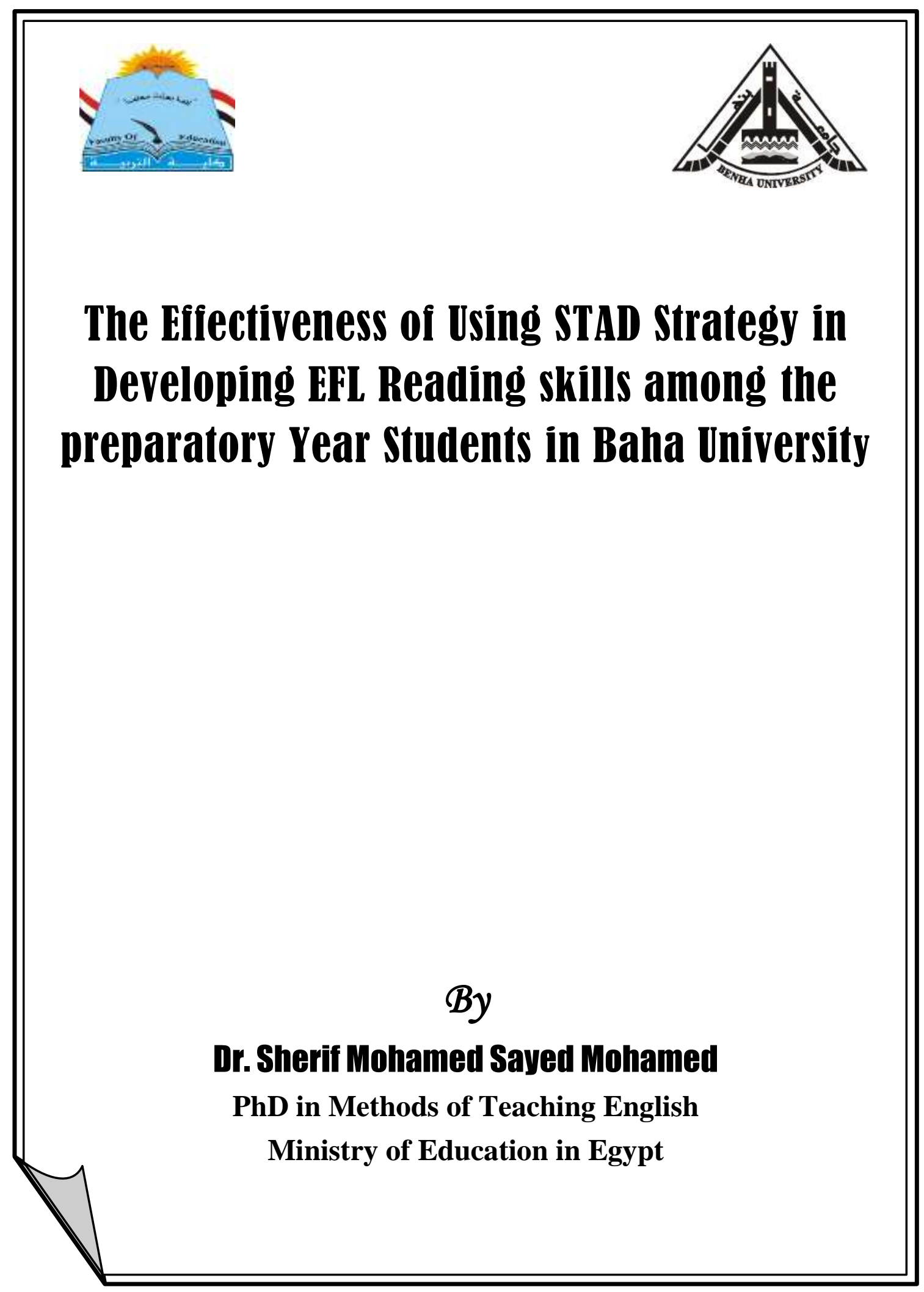




\section{The Effectiveness of Using STAD Strategy in Developing EFL Reading skills among the preparatory Year Students in Baha University}

\section{By}

Dr. Sherif Mohamed Sayed Mohamed

$\mathrm{PhD}$ in Methods of Teaching English Ministry of Education in Egypt

\section{Abstract}

The aim of this study was to investigate the effectiveness of using the STAD Strategy in developing EFL reading skills among the preparatory Year Students in Baha University. The participants included (31) preparatory Year Students in Baha University (Aqiq), Saudi Arabia. They were assigned to one experimental group. To achieve the aim of the study, the researcher prepared a reading comprehension skills checklist, a reading comprehension test 1 . The STAD Strategy was designed to develop EFL reading comprehension skills among preparatory Year Students in Baha University. T-test was used for the statistical analysis of data. Results showed that the STAD Strategy proved to be effective in enhancing preparatory Year Students' reading skills. Thus, the suggested strategy is effective in developing EFL reading comprehension skills among preparatory Year Students in Baha University.

Keywords: STAD strategy, reading skills, preparatory Year Students, Baha University.

\section{1}



القراءة باللانة الانجليزية لائي طلاب السنة التصضيرية بجامعة الباحة

\section{المستخله ص}

تهدف الدراسة الحالية إلى معرفة مدى فاعلية استخدام استراتيجية شعبة الانجاز لفرق

الطلاب في تتمية مهارات القراءة باللغة الانجليزية لاي طلاب السنة التحضيرية بجامعة الباحة. اشتملت هذه الدراسة (1/) طالب من طلاب السنة التحضيرية بجامعة الباحة (العقيق - المملكة العربية السعودية).خضع هؤلاء التلاميذ لمجموعة تجريبية واحدة وذلك لتحقيق أهداف الدراسة ثم قام الباحث بإعداد قائمة بمهارات الفهم القرائي. ثم قام الباحث باستخدام استراتيجية شعبة الانجاز لفرق الطـلاب في تتميـة مهارة القراءة باللغـة الانجليزيـة لدي طـلاب السنة التحضيرية بجامعـة الباحـة. ثم قام باستخدام اختبار (ت) في المعالجـة الإحصـائية للبيانـات. أوضـحت نتائج هذه الدراسة فعالية استراتيجية شعبة الانجاز لفرق الطلاب في تدعيم قدرة طلاب السنة التحضيرية بجامعة الباحة في مهارة القراءة. وبذلك فإن هذه الاستراتيجية فعالة في تتمية مهارة القراءة باللغة الإنجليزية لدى طلاب السنة التحضيرية بجامعة الباحة.

الكلمــات المفتاحيـة : استراتيجية شعبة الانجـاز لفرق الطـلاب، مهـارات القراءة، طـلاب السنة

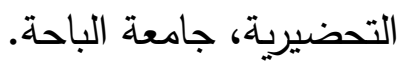




\section{Introduction}

Reading is considered one of the most important skills. It is one of the receptive skills as well as one of the oral skills. Reading is important as it is acknowledged. Nowadays, people not only learn reading, but they also should read to learn. This reflects the fact that reading is one of the life skills. It is the interpretation or comprehension of symbols that are printed or written within the core of reading and the message that the author is trying to relate to the reader.

Reading is one of the receptive skills as well as one of the oral skills. Reading is important as it is acknowledged, nowadays, people not only learn reading, but they also should read to learn. This reflects the fact that reading is one of the life skills.

It is the interpretation or comprehension of symbols that are printed or written within the core of reading and the message that the author is trying to relate to the reader. It is selective, an anticipating, purposeful and comprehending process. So, reading is not gathering rather than information interpreting. The purpose of reading is to make meaning from the words that are presented. (Serran 2002- Ibrahim 2007).

It is the process of constructing meaning by interacting with the text. As individuals read, they use their prior knowledge with clues from the text to construct meaning. It is individual activity and active process of understanding the texts in which effective readers know that when they read and monitor their understanding. It is always directed and controlled by needs and purposes of individual and depends on what individuals have acquired. It occurs when students are reading what they want to read or what they see some good reasons to read. It is influenced by the reader's perception, decoding skills, prior knowledge of the subject and reasoning capability (E-Eskey 1986\& Abdel-Hack 2006)

The purpose of teaching reading is to develop the reader's attitudes, abilities and skills needed for obtaining information, fostering, reacting to ideas, developing interests and finally deriving pleasure by reading through comprehension. Reading comprehension is one of the most important objectives of the reading process. It is the first point to be made about reading process. Comprehension depends on knowledge and 
relating what we do not know or new information to what we already know.(E.Eskey 1986, Zaza 2001)\& (Shehata 2006).

The meaningful reading is essentially cognitive process not only the reader understands the ideas, comprehension is getting meaning from the printed page as there is no meaning but only lines and curves that we happen to call letters and from which we build words. Meaning lies not on the printed page, but rather in the mind of the reader who reads the words. Reading and reading comprehension can be described as constructing and reconstructing meaning, so reading is comprehension

Active reading involves specifically attending to various cues to identify and structure concepts and ideas. Active reading helps students keep up their motivation, accomplish their study goals, and stay awake. A good method of reading actively is utilizing the STAD strategy. This strategy is based on the idea that we learn and remember texts when we create questions about the material and read to find the answers.

Every researcher has his/her specific list of reading comprehension skills. The following is the survey of some reading comprehension skills:

Cooper, Warncke and Shipnsan (1988) believe that reading skills, decoding skills or comprehension skills are referring to specific parts of reading that should be taught. The teaching of one skill after another does not mean that the reader will be skillful because the sum of parts does not equal the whole. Thonis (1988) identifies the following reading comprehension skills: a.Vocabulary knowledge; b.Main idea ; c.Factual information, i.e., students should be able to identify facts from other factual information ; d.Reading between the lines, i.e., the ability of making inferences ;e.Judging the truth and logic of the writer by critical reading; f.The ability of understanding the figurative language and its implicit meaning; g. The ability of relating what is read to what is known before hand or other material they read.

Many researchers conducted studies for developing EFL reading comprehension skills and their results were in line with the results of the present study:

Ismail (1997) conducted a study of a suggested program for developing some reading skills in English among primary pupils. Results 
of the study have shown that there are no statistical significant differences between the performance of the experimental group and that of the control group before the experiment in (phonological skill - word recognition - reading comprehension).

Ibrahim (2001) examined the effectiveness of Meta-cognitive strategy training for developing EFL students' reading comprehension. The results revealed that strategy training has proved to be vital for effective reading comprehension. Separation of cognitive and metacognitive strategies in language teaching is under questioning.

Dabbour (2001) conducted a study of a cognitive strategies program in English Language to improve reading comprehension for university students. The results revealed that cognitive reading strategies such as getting the idea quickly, guessing, prediction, summarizing, note-taking, semantic mapping, looking for markers of cohesion and self questioning were proved to be effective to improve reading comprehension among non-specialist university learners.

Abdel-Badie (2001) conducted a study on the effectiveness of Mastery learning in developing some reading skills among secondary school students. The results revealed that Bloom mastery learning strategy is effective in enhancing students' acquisition of the target reading comprehension skills of identifying the main idea, understanding relationships between sentences and ideas, drawing inferences and logical conclusions and distinguishing facts from opinions.

Abdallah (2003) conducted a study on the effectiveness of portfolio on developing the reading and writing skills of EFL students at the secondary stage.

The results revealed that the use of portfolios enhances EFL students' reading and writing skills.

\section{Literature review:}

Reading is an essential skill for learners of English. For most of learners, it is the most important skill to master in order to ensure success in learning. With strengthened reading skills, learners of English tend to make greater progress in other areas of language learning. Reading should be an active, fluent process that involves the reader and 
the reading material in building meaning. (Anderson, 2003). According to Alexander (2005), reading is more important today than it ever wasitis crucial to develop this ability in order for students to succeed in their chosen career because so much of information is communicated in written form. Therefore, readingis the most fundamental skill a student will ever acquire. Supporting the same idea.

Mokhtari and Sheorey (2008) pointed out that reading and learning are interrelated ineducation. Reading is a significant element for academic success. Regardless of theage of the learner, Reading is the key component for academic success of non-native English speaking students because they are required to read various textbooks ormaterials for getting information and learning.

There are various definitions for this term. Cooper (1995) defined reading skills asspeed plus a variety of skills, depending on the purpose and text- type, while Afflerbach, Pearson and Paris (2008) defined reading skills as automatic actions thatresult in the decoding and comprehending of texts with speed, efficiency, and fluency, usually without the reader's awareness of the components or controls involved. They are tactics that are mastered and unintentionally used by the reader tocomprehened reading. Leane (2002) mentioned that there are a number of skills that can be taught to help students improve their ability to understand and process a text. Basically there are three types of reading activities, namely; pre- reading, during- reading and post reading. Pre- reading activities prepare the students for reading the text. They help the students gain an idea of what the text will be about and this increases their motivationto read. During- reading activities improve their ability to interact and understand the text whereas post-reading activities which help students to critically analyze whatthey have read. post-reading activities also increase the students understanding of thetext. Greenall and swan (1990) determined some reading skills, which we should teach students such as extracting main ideas, reading for specific information, understanding text structure, predicting, checking comprehension, inferring, dealing with unfamiliar words, linking ideas, understanding complex sentence, understanding writer's style, evaluating the text, reacting to the text and writing summaries. Macmillan (2002) also clarified some of reading skills as skimming, scanning, identifying 
key words, pronoun reference, using cognates, guessing meaning, information transfer, identifying the topic sentence, summarizing, identifying the source of written material and reading for gist. Leane (2002) reported that predicting is a pre-reading skill. It involves using cues in the text to guess what is going to come next. Understanding the context of what they have already read helps students to make predictions. They can also use theillustrations, vocabulary or the grammatical structure to guess what is coming next. Scanning and skimming are while-reading skills.

Dabbour (2001) examined a cognitive strategies program in English language to improve reading comprehension for university students - at the faculty of languages and translation were equally assigned into a control and experimental groups. The experimental group received the cognitive reading strategies program that focused on summarizing, self questioning, predicting, guessing the meaning of words, semantic mapping, looking for markers of cohesion, note taking and getting the idea quickly. While the control group received ten English course. Results of the study indicated that the subjects of the experimental group tended to be proficient ininterpreting texts. This lends support to the notion that cognitive reading strategiesplay a significant role in the ability to comprehend a text.

Sheu (2004) Investigated the effect of an extensive reading program (ERP) on the reading development and learning attitudes of Taiwanese 2nd-year junior high school students. In each study, two ERP groups using graded readers (GR) and books for native English speaking children (BNESC) respectively, and one control groupreceiving grammar-based instruction, were involved. The results showed that the longer the learners are immersed in a pleasurable and meaning fulenvironment, the bigger the benefits they will receive.

Tarim. K \& Akdeniz. F (2008) aimed at comparing the effects of Team Assisted Individualization (TAI) and Student Teams-Achievement Divisions (STAD) on fourth grade students' academic achievement in and attitudes towards mathematics. Seven classes of a school were randomly selected for this experimental study. Two of these were given instruction through TAI; two through STAD, and the remaining three were treated as 
a control group. For the purpose of the data analysis regarding academic achievement, the 3 X 1 covariance analysis was used to compare the groups. As a result of this comparison, both the TAI and STAD methods were found to have positive effects $(d=1.003$ for TAI and $d=0.40$ for STAD) on students' academic achievement in mathematics. The pairwise comparisons showed that the TAI method had a more significant effect than the STAD method. The scores for the attitude towards mathematics. Mathematics were analyzed by using non-parametric statistics. As a result of this analysis, no significant difference was observed regarding students' attitudes towards mathematics. Tawfeek (2009) investigated the effectiveness of the Jigsaw method in Developing English reading skills of First year prep school pupils. Fifty pupils enrolled in the first year, Taha Hussein, prep school were the subjects of this study.

They were divided into two groups, each consists of twenty-five pupils. The experimental group pupils were taught by the Jig saw II method As for the control group, they were taught using the common method Results showed the effectiveness of the Jig saw II method in developing the reading skills of first year prep school pupils. Megria (2010) conducted a study on the effectiveness of using content based instruction in improving reading comprehension skills and scientific concepts amongprimary school pupils. The study sample consisted of 80 pupils from Barheemexperimental primary school and shebeen El-houm experimental primary school and was divided into two groups: 40 pupils for the experimental group and 40 pupils for the control group. The experimental group pupils were taught through content based instruction and the control group pupils were taught through the traditional method. The results revealed that content based instruction approach proved to be highly effective in improving fourth year primary school pupils' reading comprehensionskills and scientific concepts in English. El-Garawany (2010) investigated the effects of repeated reading strategies on Developing oral reading fluency and reading comprehension among EFL prospectiveteachers - The subjects were 60 third year students enrolled in the English section, faculty of education , Menoufia University, during the second semester of the 2008 - 2009 academic year - The subjects were chosen a random and divided into twogroups: The experimental group $(\mathrm{N}=30)$ and the control $(\mathrm{N}=30)$. The experimentalgroup students were exposed to the repeated reading strategies program. However,the subjects of the control group were taught in the 
regular way. The results revealedthat the experimental group students made significant gains in oral reading fluencywith its three components and reading comprehension. Thus, the repeated reading strategies program proved to be effective in developing students' oral reading fluency and reading comprehension. Farag (2011) examined the use of the electronic book in developing English reading skills among second year preparatory students. Eighty six of second year preparatory school students, representing two classes at Hussein El-Ghorab prep school constituted the subjects of the study. They were divided into two groups; theexperimental group ( $\mathrm{N}=43)$ and the control group $(\mathrm{N}=43)$. The e-book was taughtto the experimental group whereas the control group students were taught the regularbook Results of the study showed that the use of the e-book is more effective than there gular book in developing English reading skills among the second year prep school students. Al- Ahmadi\& Koura (2012) examined the effectiveness of using SQ3R strategy in Developing the reading comprehension skills of secondary school students. The subjects of this study consisted of 47 . Second secondary school EFL students were divided into two groups. The experimental group (24) and the ontrolgroup (23) students. Results of the study revealed that the effectiveness of SQ3Rstrategy was evident in improving all the fourteen reading comprehension skills. Ghoneim (2012) developed the effectiveness of thinking maps on the preparatory students' development of EFL inferential reading comprehension of firstyear prep school pupils. The researcher used eight thinking maps while teaching reading texts to the experimental group to help them develop higher order thinking skills. The control group studied the same reading lessons using the regular waycommonly used in teaching reading. The findings showed that there were significant differences between the mean scores of the experimental group and those of the control group and those of the control group in favour of the experimental group.

Warawudhi. R (2012) investigated the differences between the Lecture Method (LM) and the Student Teams Achievement Division (STAD) for teaching English reading skills at Burapha University, Thailand. The subjects were 154 Thai undergraduate students of whom 82 were in the Experimental Group $(\mathrm{N}=82)$ and 72 in the controlled group $(\mathrm{N}=72)$. The triangulation methods were used to collect the students' reading achievements, the students' and teacher's attitudes towards the 
two teaching approaches. The results show that students participated more in the STAD class. Both teacher and students were more satisfied with this collaborative learning as well. It is therefore concluded that STAD can be an alternative teaching method for reading skill for English. AbdelAziz (2013) aimed at investigating the effectiveness of a mind map strategy on developing third year preparatory stage students' reading comprehensionskills. Two third year prep classes were randomly selected from Taba mixed Experimental prep school, in the academic year 2012 2013 one class was taught through a mind mapping strategy to represent the experimental group and the other class received regular instruction to represent the control group. Findings of the study showed the effectiveness of the mind mapping strategy on developing third year prepstudent reading comprehension.

Sirisrimangkorn. L, Suwanthep. J (2013) aimed at investigating the pedagogical use of integrated drama-based role play and Student Teams Achievement Division (STAD) cooperative learning, and its effects on the first year non-English majors' speaking skills, motivation, and self-esteem. The study was conducted over an academic semester in a basic English class in a northeastern university in Thailand with two separate groups, with a quasi-experimental design. The participants in this study were 80 non-native undergraduate students whose major was not English. Over the 16 weeks of the study, both groups of students studied English with the same learning content; however, only the experimental group was introduced to drama-based role play and STAD, with blended-learning instruction, while the control group continued using the course book role plays with regular group work activities and classroom instruction. Both quantitative ( $t$-test) and qualitative (content analysis) methods were used to analyze the results of the study. The results of the quantitative and qualitative analysis showed the effectiveness of drama-based role play combined with STAD on students' speaking skills, motivation, and self-esteem in the experimental group. The study concludes with recommendations for the integration of the blended drama-based and cooperative learning to improve students' English speaking skills and affective involvement.

The above review of the previous studies also served the present study in different ways. The researcher benefited from these studies in 
designing the instruments of the present study. These previous studies also presented deeper insight into reading comprehension. They helped the researcher in designing pre and post tests for measuring the students' progress in the sub skills of reading comprehension.

\section{The aim and research questions of the study:}

The aim of the current study is to develop EFL reading skills among the preparatory year students in Baha University through the STAD Strategy.

The problem of this study could be stated in the following questions:

1- What are the EFL reading comprehension skills required for the preparatory year students in Baha University?

2- To what extent are preparatory year students in Baha University proficient in the EFL reading comprehension skills?

3- What are the bases of the STAD strategy in developing the EFL reading comprehension skills?

4- What is the effectiveness of the STAD strategy in developing EFL reading comprehension skills?

\section{Method}

\section{Participants}

Thirty- one preparatory year students in Baha Universitywere involved in the study. The subjectswere enrolled in one group in preparatory year in Baha University, Saudi Arabia. The sample's ages ranged between 17 to 18 years old.

\section{Research instruments}

To fulfill the aim of the study, the researcher prepared the following Instruments:

1- A pre- reading test to measure some EFL reading skills among preparatory Year Students in Baha University.

2- A post reading test to measure the effectiveness of the STAD Strategy in developing EFL reading skills among preparatory Year Students in Baha University through measuring some EFL reading skills among the preparatory Year Students after implementing the suggested strategy. 


\section{Construction of the Reading Comprehension pre \& post tests}

Objectives of the Two Tests:

The reading comprehension pre \&post tests aimed at measuring some EFL reading comprehension skills among preparatory year students in Baha University. More specifically, the tests attempted to measure students' ability to:

\section{1- Deal with literal comprehension skills through:}

a) Determining the meaning of words from context

b) Recognizing the main idea

c) Identifying supporting details

\section{2- Deal with critical comprehension skills through:}

a) Recognizing the author's purpose

b) Identifying relationships between sentences

c) Drawing logical conclusions.

\section{Description of the Reading Comprehension pre-test:}

The reading comprehension pre-test was designed to diagnose some EFL reading comprehension difficulties encountered by preparatory Year Students in Baha University. So the test was designed to measure certain skills needed for dealing with difficult words.

It consists of one passage. This was followed by eight questions.

\section{Piloting the reading comprehension pre-test:}

The test was administered to a pilot sample of 31preparatory Year Students in Baha University for the sake of:

1- Making sure that the questions were understood by students.

2- Setting the time limit.

Time was determined by calculating the mean time, which the fastest students and the slowest ones took in answering the test. It was found that the time needed to answer the test was one hour and forty minutes (100 minutes). 


\section{Validity of the reading comprehension pre-test:}

In order to achieve the validity of the test, it was submitted to a jury of specialists in curriculum and methods of teaching English .

They were requested to read the passages and the questions and give their opinions concerning:

1- The suitability of content.

2- The difficulty and length of the passages.

3- How far each question measures the skill intended to measure.

\section{Reliability of the reading comprehension pre-test:}

To measure the reliability of the test, the test re-test method was used. The test was administered to a group of preparatory Year Students in Baha University, Aqiq (Saudi Arabia) $(\mathrm{N}=31)$. The test was readministered to the same sample one week later using the Pearson Formula, the reliability co-efficient was 0.953 which is statistically significant at 0.01 level. So, the reading comprehension test " 1 " is reliable. Table "4" shows the correlation and reliability co-efficient obtained.

Table (1): Correlations of the students' Scores in the first application and their marks in the second application

\begin{tabular}{||c|c|c|c|}
\hline \multicolumn{2}{|c|}{} & Test 1 Pre & Test 1 Pos \\
\hline \hline Test "1" & Pearson Correlation & 1.000 & $.953 * *$ \\
Pre & Sig. (2 - tailed) & 31 & 0.000 \\
& $\mathrm{~N}$ & & 31 \\
\hline
\end{tabular}

** Correlation is significant at the 0.01 level $(2$ - tailed $)$

\section{Description of the Reading Comprehension post-test:}

The reading comprehension post-test was designed to diagnose some EFL reading comprehension difficulties encountered by preparatory Year Students in Baha University. So the test was designed to measure certain skills needed for dealing with difficult words.

It consists of one passage followed by eight questions. Piloting the reading comprehension test " 2 ": 
The test was administered to a pilot sample of 31 preparatory Year Students in Baha University for the sake of:

1- Making sure that the questions were understood by students.

2- Setting the time limit.

Time was determined by calculating the mean time, which the fastest students and the slowest ones took in answering the test. It was found that the time needed to answer the test was one hour and forty minutes (100 minutes).

\section{Validity of the reading comprehension post- test:}

In order to achieve the validity of the test, it was submitted to a jury of specialists in curriculum and methods of teaching English. They were requested to read the passages and the questions and give their opinions concerning:

1- The suitability of the content.

2- The difficulty and length of the passages.

3- How far each question measures the skill intended to measure.

\section{Reliability of the reading comprehension post- test:}

To measure the reliability of post-test, the test re-test method was used. The test was administered to a group of 31preparatory Year Students in Baha University, Aqiq (Saudi Arabia) $(\mathrm{N}=31)$. The same test was readministered to the same sample one week later using the Pearson Formula. The reliability co-efficient was 0.943 which is statistically significant at 0.01 level. So, the reading comprehension test is reliable. Table (4) shows the correlation and reliability co-efficient obtained.

Table (2): Correlations of the students' marks in the first application and their marks in the second application

\begin{tabular}{|c|c|c|c|}
\hline & & Test 2 Pre & Test 2 Pos \\
\hline \hline Test "2" & Pearson Correlation & 1.000 & $.943^{* *}$ \\
Pre & Sig. (2 - tailed) & 31 & .000 \\
& $\mathrm{~N}$ & 31 \\
\hline
\end{tabular}

** Correlation is significant at the 0.01 level $(2$ - tailed $)$ 


\section{Statistical validity of reading comprehension pre-test and post-test:}

The Statistical validity of reading comprehension pre \& post tests was measured by criterion-reference validity. This was achieved by computing the co-efficient between the two tests. Using the Pearson Formula, the validity co-efficient was 0.834 , which is statistically significant at 0.01 level. So, the reading comprehension pre \& post tests are valid. Table (5) shows the correlations and validity co-efficient obtained.

Table (3): Correlations of the reading comprehension pre $\&$ post tests:

\begin{tabular}{|c|c|c|c|}
\hline \multicolumn{2}{|c|}{} & Test 1 PRE & Test 2 POS \\
\hline \hline Test "1" & Pearson Correlation & 1.000 & $.834^{* *}$ \\
PRE & Sig. (2 - tailed) & 31 & .000 \\
& $\mathrm{~N}$ & & 31 \\
\hline
\end{tabular}

** Correlation is significant at the 0.01 level $(2$ - tailed $)$

\section{Construction of the suggested program (The STAD-based program):}

Based on the previous conclusions of literature related to STAD strategy, and the EFL reading comprehension skills list, the following was done:

1- The objectives of the program were stated.

2- The materials were selected, developed and organized.

3- The program was designed (App. E).

4- The teaching and learning activities were specified.

5- Evaluation procedures and time were determined.

\section{Purpose of the program:}

The main purpose of the Suggested Program is to develop the preparatory Year Students in Baha UniversityEFL reading comprehension skills through STAD Strategy.

\section{Content of the program:}

STAD is composed of five components:

- class presentations 
- work in teams

- quizzes

- individual improvement scores

- team recognition. Each component is integrated in order to promote students' English learning through drama-based role play.

As for the first component, the 'class presentations' are based on students' learning on the content provided by the teacher. The students are required to approach the content through e-learning before actual classroom instruction. The second component, the 'team' component, encourages students to learn and work cooperatively with their classmates. During the process, the students work in teams based on team assignments and co-creation scripts. 'Quizzes' make up the third component, focusing on the individual accountability of each student. They are supposed to perform better in each quiz so that they earn improvement scores for their team. The fourth component, 'individual improvement scores', encourages the students to make an effort and develop their own learning. Each learner's improvement scores can contribute to their team performance. Finally, 'team recognition', the last component, urges all members in each team to work together in order to get the team reward.

\section{Validity of the program:}

In order to establish the validity of the program and its relevance to preparatory Year Students in Baha University, two procedures were followed:

1- Submitting the program to a jury of specialized in TEFL

2- Piloting a sample of the lessons in the program on a group of the first year secondary school students to determine the following:

a) The feasibility and relevance of the reading course of the target population.

b) Timing of the lessons and the activities

c) The level of difficulty of the activities

The students of the piloting sample declared the following:

- Some of the activities were too difficult for them so, they were modified. 
- Some lessons took more time than expected, so, the number of activities was decreased.

Based on the aforementioned results of the piloting and the recommendations of the jury members, the program was modified. Some activities were changed and then the program was revised and prepared in its final form.

\section{Procedures followed in the experimentation:}

The experimentation proceeded as follows:

1- After the program was designed, validated and revised, the sample of the study was one Study Sample. The Study Sample included 31 students.

2- At the beginning of the first semester of the academic year 20192020 , namely, the pre-test was administered to the study subjects to identify their pre-level in the target sub-skills of EFL reading comprehension skills.

3- The STAD Strategy was clarified to the Study Sample during the first term of the academic year 2019-2020 for 3 months.

4- After conducting the program, the reading comprehension post test was administered to the subjects in the first week of January 2020 to measure the effectiveness of STAD Strategy as well as deciding which sub-skills of EFL reading comprehension skills improved higher than others as a result of the experimental treatment.

5- Pre and post experimental results were calculated, compared and discussed. Recommendations were suggested.

\section{The approach to teaching the program}

This program is based on the STAD strategy. Students abound in EFL reading comprehension activities that encompass the best of research on learning and teaching a foreign language and require active participation of the students who themselves develop many of the EFL reading comprehension skills. 


\section{Pre-reading activities:}

\section{1- Brainstorming}

\section{Teacher's role:}

- Ask students to close their books.

- Distribute one worksheet for each group.

- Ask Ss to write vocabularies about the housework in three groups; male housework, female housework and general housework for any sexes.

- Monitor the class to see if Ss need more explanation.

- Show each group's worksheet on visualizer and check the answers for scoring.

\section{Students' role:}

- Close the book.

- Work ingroup and brainstorm thenewvocabularies about the housework in three groups; male housework, female housework and general housework form any sexes.

- Ss help write theanswers on the worksheet inlimited time.

- Hand in the worksheet.

- Look on the screen and help teacher for spelling-check. Misspelling words will not be counted.

\section{2- Reading for gist / main idea}

\section{Teacher's role:}

- Read the questions for gist with the class.

- Ask for the answer from the class.

- Show the prepared answers on the screen and explain.

- Ask Ss to read the questions for main idea.

\section{Students' role:}

- Read the questions forgist.

- Scan the reading and consult with the group for answers.

- Check their answers with the keys.

- Read the questions for main idea with their group. 


\section{3- Midreading activity}

\section{Teacher's role:}

- Distribute fishbone chart for each group.

- Ask Ss to work in the group help each other with the reading.

- Ask Ss to complete fishbone.

- Show the prepared answers on the screen and explain.

- Score each group according to their performance.

\section{Students' role:}

- Work in group filling in the fishbone with the names and reasons for their opinion towards the housework.

- Hand in the worksheet.

- Check their answers with the keys.

\section{4- Post-reading activity}

\section{Teacher's role:}

- Ask Ss to reread the questions for main idea.

- Ask each group to write the answers from questions for main idea in provided paper.

- Ask Ss to cross check their answers with other groups.

- Show the answers on visualizer.

\section{Students' role:}

- Consult with their teammate to find the answer.

- Write the answers and hand in the answer paper.

- Check the answer of other group. Ask the teacher if they can make decision to score answers from other group.

\section{Data Analysis and Results of the Study:}

This chapter presents the statistical analysis of the data and the study results. The results of the present study are presented by relating them to the hypotheses of the study. Both the reading comprehension test 1 and test 2 were scored by the researcher.

For scoring the reading comprehension test 1 , the questions were given (9) marks in the questions for dealing with determining meaning of words from context. The questions were given (11.5) marks for 
identifying supporting details. The questions were given (6) marks for the identifying relationships between sentences.

In addition, the questions were given (5) marks for recognizing the author's purpose. The questions were also given (3.5) marks for the ability to recognize the main idea. The questions were given (5) marks for the ability to draw logical conclusions. The questions were given (zero) for the wrong answer. Hence, the total score for the reading comprehension test 1 was (40) marks.

For scoring the reading comprehension test 2, the questions were given (7.5) marks in the questions for dealing with determining meaning of words from context. The questions were given (10.5) marks for identifying supporting details. The questions were given (11) marks for the identifying relationships between sentences.

In addition, the questions were given (3.5) marks for recognizing the author's purpose. The questions were also given (3.5) marks for the ability to recognize the main idea. The questions were given (4) marks for the ability to draw logical conclusions. The questions were given (zero) for the wrong answer. Hence, the total score for the reading comprehension test 1 was (40) marks.

The data was analyzed according to both descriptive statistics (mean and standard deviation) and inferential statistics (T-test).

\section{Hypothesis (1):}

To verify if the first hypothesis, i.e., "There is a statistically significant difference in determining meaning of words from context between the mean scores of the Study Sample on the reading comprehension test 1 results and those of the reading comprehension test 2 results in favour of the reading comprehension test $2, "$ is true or not, the means, standard deviations and the t-test were calculated.

Table (4)the T-value of the means of difference in the Study Sample scores on the reading comprehension pre \& post tests in determining meaning of words from context.

\begin{tabular}{|c|c|c|c|c|c|c|c|}
\hline Skill & Test & $\mathbf{N}$ & Mean & S.D & "T" value & df $\begin{array}{c}\text { Sig. (2- } \\
\text { tailed) }\end{array}$ \\
\hline "Determining meaning of words & Test 1 & 31 & 3.667 & 2.713 & \multirow{2}{*}{3.241} & 20 & 0.01 \\
\cline { 2 - 4 } \begin{tabular}{c} 
from context" \\
\cline { 2 - 4 }
\end{tabular} & Test 2 & 31 & 5.357 & 1.726 & & \\
\hline
\end{tabular}


Thus, table 4 indicates that the t-value is significant at the level of 0.01 . This proved that there is a statistically significant difference between the mean scores of the Study Sample on the reading comprehension pre-test and their mean scores on the reading comprehension post- test in favour of the mean scores on the reading comprehension post-test in determining meaning of words from context. Therefore, this hypothesis was statistically supported.

\section{Hypothesis (2):}

In order to investigate the validity of the second hypothesis, i.e., "There is a statistically significant difference in recognizing the main idea between the mean scores of the Study Sample on the reading comprehension pre-test results and those of the reading comprehension post-test results in favour of the reading comprehension post-test ," is true or not, the means, standard deviations and the t-test were calculated. the t-test was calculated.

Table (5) the t-value of the means of the difference in the Study Sample scores on the reading comprehension pre-test and post-test in recognizing the main idea.

\begin{tabular}{||c|c|c|c|c|c|c|c|}
\hline Skill & Test & N & Mean & S.D & "T" value & df & $\begin{array}{c}\text { Sig.(2- } \\
\text { tailed) }\end{array}$ \\
\hline "Recognizing the main idea" & Test I & 31 & 1.667 & 1.790 & \multirow{2}{*}{4.690} & 20 & 0.01 \\
\cline { 2 - 6 } & Test2 & 31 & 3.500 & 0.00 & & \\
\hline
\end{tabular}

Thus, table 5 indicates that the t-value is significant at the level of 0.01. This

proved that there is a statistically significant difference between the mean scores of the Study Sample on the reading comprehension pre-test and their mean scores on the reading comprehension post-test in favour of the mean scores on the reading comprehension post- test in recognizing the main idea. So, this hypothesis was statistically supported.

\section{Hypothesis (3):}

To verify the third hypothesis, i.e., "There is a statistically significant difference in identifying supporting details between the mean scores of the Study Sample on the reading comprehension pre-test results 
and those of the reading comprehension post-test results in favour of the reading comprehension post- test ", the means, standard deviations and the t-test were calculated.

Table (6) t-value of the means of the difference in the Study Sample scores on the reading comprehension pre-test and post- test in identifying supporting details.

\begin{tabular}{|c|c|c|c|c|c|c|c|}
\hline Skill & Test & $\mathrm{N}$ & Mean & S.D & "T" value & df & $\begin{array}{c}\text { Sig. } \\
\text { (2-tailed) }\end{array}$ \\
\hline \hline "Identifying supporting details" & Test 1 & 31 & 5.238 & 1.998 & \multirow{2}{*}{5.181} & 20 & 0.01 \\
\cline { 2 - 8 } & Test 2 & 31 & 7.952 & 2.229 & & \\
\hline
\end{tabular}

Thus, table 6 indicates that the t-value is significant at the level of 0.01 . This proved that there is a statistically significant difference between the mean scores of the Study Sample on the reading comprehension test 1 and their mean scores on the reading comprehension post-test in favour of the mean scores on the reading comprehension post-test in identifying supporting details. Therefore, this hypothesis was statistically supported.

\section{Hypothesis (4):}

To verify the fourth hypothesis, i.e., "There is a statistically significant difference in total literal comprehension skills between the mean scores of the Study Sample on the reading comprehension pre-test results and those of the reading comprehension post-test results in favour of the reading comprehension post-test ,"

the means, standard deviations and the t-test were calculated.

Table (7) $t$-value of the means of the difference in the Study Sample scores on the reading comprehension pre \&post tests

in total literal comprehension skills.

\begin{tabular}{|c|c|c|c|c|c|c|c|}
\hline Skill & Test & $\mathbf{N}$ & Mean & S.D & "T" value & df & $\begin{array}{l}\text { Sig. }(2- \\
\text { thiled) }\end{array}$ \\
\hline $\begin{array}{c}\text { "Total literal comprehension } \\
\text { skills" }\end{array}$ & $\begin{array}{c}\text { Test1 } \\
1 \\
\text { Test } 2 \\
2\end{array}$ & $\begin{array}{l}31 \\
31\end{array}$ & $\begin{array}{l}10.571 \\
16.809\end{array}$ & $\begin{array}{l}4.296 \\
3.215\end{array}$ & 6.759 & $\begin{array}{l}20 \\
20\end{array}$ & 0.01 \\
\hline
\end{tabular}


The previous table indicates that the t-value is significant at the level of 0.01 . This proved that there is a statistically significant difference between the mean scores of the Study Sample on the reading comprehension test 1 and their mean scores on the reading comprehension test 2 in favour of the mean scores on the reading comprehension test 2 in total literal comprehension skills. Thus, this hypothesis was statistically supported.

\section{Hypothesis (5):}

In order to validate the fifth hypothesis, i.e. "There is a statistically significant difference in recognizing the author's purpose between the mean scores of the Study Sample on the reading comprehension pre-test results and those of the reading comprehension post-test results in favour of the reading comprehension post-test, " the means, standard deviations and the t-test were calculated.

Table (8)" T-value of the means of the difference in the Study Sample scores on the reading comprehension pre \&post tests in recognizing the author's purpose.

\begin{tabular}{|c|c|c|c|c|c|c|c|}
\hline Skill & Test & $\mathbf{N}$ & Mean & S.D & "T" value & df & Sig. 2-tailed \\
\hline \hline $\begin{array}{c}\text { "Recognizing the author's } \\
\text { purpose" }\end{array}$ & Test 1 & 31 & 1.429 & 2.315 & \multirow{2}{*}{4.101} & 20 & \multirow{2}{*}{0.01} \\
\hline
\end{tabular}

Thus, table 8 indicates that the $\mathrm{t}$-value is significant at the level of 0.01 . This proved that there is a statistically significant difference between the mean scores of the Study Sample on the reading comprehension test 1 and their mean scores on the reading comprehension test 2 in favour of the mean scores on the reading comprehension test 2 in the ability to deal with recognizing the author's purpose. Therefore, this hypothesis was statistically supported.

\section{Hypothesis (6):}

To verify the sixth hypothesis, i.e., "There is a statistically significant difference in the ability to identify relationships between sentences between the mean scores of the Study Sample on the reading comprehension test 1 results and those of the reading comprehension test 2 results in favour of the reading comprehension test 2," the means, standard deviations and the t-test were calculated. 
Table (9) the t-value of the means of the difference in the Study

Sample scores on the reading comprehension pre-test \&post test in the ability to identify relationships between sentences.

\begin{tabular}{|c|c|c|c|c|c|c|c|}
\hline Skill & Test & $\mathbf{N}$ & Mean & S.D & "T" value & df & \begin{tabular}{|l|} 
Sig. (2-tailed) \\
0.01
\end{tabular} \\
\hline "Identify relationships & $\begin{array}{l}\text { Test } 1 \\
\text { Test } 2\end{array}$ & \begin{tabular}{|l|}
31 \\
31
\end{tabular} & $\begin{array}{l}3.809 \\
8048\end{array}$ & $\begin{array}{l}1.887 \\
2.474\end{array}$ & 9.632 & $\begin{array}{l}20 \\
20\end{array}$ & 0.01 \\
\hline
\end{tabular}

Thus, table 9 shows that the t-value is significant at the level of 0.01 . This proved that there is a statistically significant difference between the mean scores of the Study Sample on the reading comprehension pre-test and their mean scores on the reading comprehension post- test in favor of the mean scores on the reading comprehension post-test in the ability to identify relationships between sentences. There, this hypothesis was statistically supported.

\section{Hypothesis (7):}

In order to validate the seventh hypothesis, i.e., "There is statistically significant difference in drawing logical conclusions between the mean scores of the Study Sample on the reading comprehension pretest results and those of the reading comprehension post-test results" the means, standard deviations and the t-test were calculated.

Table (10) T-value of the means of the difference in the Study Sample scores on the reading comprehension pre-test and reading comprehension post- test in drawing logical conclusions.

\begin{tabular}{|c|c|c|c|c|c|c|c|}
\hline Skill & Test & $\mathbf{N}$ & Mean & S.D & "T" value & df & Sig.(2-tailed) \\
\hline $\begin{array}{c}\text { "Drawing logical } \\
\text { conclusions" }\end{array}$ & $\begin{array}{l}\text { Test } 1 \\
\text { Test } 2\end{array}$ & $\begin{array}{l}31 \\
31\end{array}$ & $\begin{array}{l}1.833 \\
2.309\end{array}$ & $\begin{array}{l}1.623 \\
0.766\end{array}$ & 1.719 & 20 & - \\
\hline
\end{tabular}

Thus, table 10 indicates that the t-value is not significant. This proved that there is no statistically significant difference between the mean scores of the Study Sample on the reading comprehension pre- test and their mean scores on the reading comprehension posttest in drawing logical conclusions. Therefore, this hypothesis was statistically rejected. 


\section{Hypothesis (8):}

In order to validate the eighth hypothesis, i.e., "There is statistically significant difference in total critical comprehension skills between the mean scores of the Study Sample on the reading comprehension pre- test results and those of the reading comprehension post- test results", the means, standard deviations and the t-test were calculated.

Table (11) T-value of the means of the difference in the Study Sample scores on the reading comprehension pre-test and reading comprehension post-test in total critical comprehension skills.

\begin{tabular}{|c|c|c|c|c|c|c|c|}
\hline Skill & Test & $\mathbf{N}$ & Mean & S.D & "T" value & df & Sig.(2-tailed) \\
\hline $\begin{array}{c}\text { "total critical } \\
\text { comprehension skills" }\end{array}$ & $\begin{array}{l}\text { Test } 1 \\
\text { Test } 2\end{array}$ & $\begin{array}{l}31 \\
31\end{array}$ & $\begin{array}{c}7.071 \\
13.191\end{array}$ & $\begin{array}{l}4.232 \\
4.036\end{array}$ & 6.569 & 20 & 0.01 \\
\hline
\end{tabular}

Thus, table 11 indicates that the t-value is significant at the level of 0.01 . This proved that there is a statistically significant difference between the mean scores of the Study Sample on the reading comprehension pre-test and their mean scores on the reading comprehension post- test in total critical comprehension skills in favor of the mean scores on the reading comprehension post-test in total critical comprehension skills. Thus, this hypothesis was statistically supported.

\section{Hypothesis (9):}

In order to validate the ninth hypothesis, i.e., "There is statistically significant difference in total reading comprehension skills between the mean scores of the Study Sample on the reading comprehension pre-test results and those of the reading comprehension post- test results", the means, standard deviations and the t-test were calculated.

Table (12) T-value of the means of the difference in the Study Sample scores on the reading comprehension pre-test and reading comprehension post-test in total reading comprehension skills.

\begin{tabular}{|c|c|c|c|c|c|c|c|}
\hline Skill & Test & $\mathbf{N}$ & Mean & S.D & "T" value & df & Sig.(2-tailed) \\
\hline $\begin{array}{c}\text { "total reading } \\
\text { comprehension skills" }\end{array}$ & $\begin{array}{l}\text { Test } 1 \\
\text { Test } 2\end{array}$ & & $\begin{array}{l}17.643 \\
30.00\end{array}$ & $\begin{array}{l}6.552 \\
6.319\end{array}$ & 11.213 & 20 & 0.01 \\
\hline
\end{tabular}

Thus, table 12 indicates that the t-value is significant at the level of 0.01 . This proved that there is a statistically significant difference 
between the mean scores of the Study Sample on the reading comprehension pre- test and their mean scores on the reading comprehension post-test in total reading comprehension skills in favor of the mean scores on the reading comprehension post-test in total reading comprehension skills. Thus, this hypothesis was statistically supported.

\section{Discussion of Results and conclusion:}

The results of the present study revealed the effectiveness of the STAD strategy in developing EFL reading comprehension skills. Therefore, it can be argued that the STAD Strategy proved to be statistically and educationally significant in developing the study sample's overall literal comprehension skills. The steps of the STAD Strategy given to the study sample during applying the program have helped the students of the study sample activate and develop the students' overall literal comprehension skills. This development may be due to the nature of the program and the techniques used in applying it.

At the end, the researcher summed up that the study sample out performed on the post test in the determining meaning of words from context, recognizing the main idea, identifying supporting details sub-skills and the overall literal comprehension skills. The study sample out performed on the post test in recognizing the author's purpose, identifying relationships between sentences sub-skills and the overall critical comprehension skills. On the other hand, there was no statistically significant difference in the mean scores of the study sample on the pre and post tests in drawing logical conclusions sub skill because first year secondary school students are not willing enough to draw conclusions and the STAD program didn't include sessions to develop the sub skill of drawing logical conclusions. The nine hypotheses of the study were accepted except the seventh one . By these results, the researcher got assured that the STAD strategy steps were effective in developing Preparatory Year students' EFL reading comprehension skills in Baha University.

\section{Recommendations:}

Based on the previously discussed results, the following recommendations could be presented:

1- Teachers should emphasize the development of the students' reading comprehension skills in early educational stages in order to develop throughout following stages to prevent any possible reading comprehension difficulties the students may face. 
2- Students should be provided with authentic and real learning situations that might help in developing their reading comprehension skills.

3- It is necessary to devote more time in English language teaching to teaching reading comprehension skills.

4- University students should be given the opportunity to participate in activities which foster their motivation for learning reading comprehension skills.

5- There should more emphasis on the STAD strategy in teaching English courses especially to Preparatory Year students in Baha University

6- Lecturers of English should teach the students how to use the STAD strategy

7- in reading texts in order to help them master any difficulties they face.

8- The STAD Strategy should be utilized for treating EFL reading comprehension difficulties which University students encounter during reading.

\section{Suggestions for Further Research:}

In view of the findings of the present study, the following suggestions are suggested to be later investigated:

1- Further research is needed to investigate the effect of the STAD strategy for developing other EFL reading comprehension skills.

2- Further research is needed to investigate the effect of using the STAD strategy on teaching writing in English.

3- Further research is needed to investigate the use of the STAD strategy to develop EFL language skills among prep school students.

4- Further research is also needed to investigate the effect of the STAD strategy on various EFL reading skills at various educational stages

5- Further research is also needed to investigate the influence of using the STAD strategy with the computer on developing the language skills. 


\section{Bibliography}

Abdallah, S. (2003). The effectiveness of portfolio on developing the reading and writing skills of EFL students at the secondary stage. Ph.D. thesis. Ain Shams University.

Abdel Aziz, M. (2013). Mind mapping and its effect on developing reading comprehension of preparatory stage students. Ain Shams University occasionalpapers in the development of English language education. Vol 55.

Abdel Badie, M. (2001). The Effectiveness of Mastery Learning in DevelopingSome Reading Skills among Secondary School Students. M.A. thesis. Zagazig University.

Abdel Hack, E. (2006).The effectiveness of using reciprocal teaching in improving strategic reading and reading comprehension skills of EFL majors. Studies in curriculum and instruction, 113, 1- 35.

Afflerbach, P., pearson, P.D., and Paris, S. (2008). Skills and strategies: Their differences, their relationships, and why it matters. In K. Mohtari and R. sheorey ( $E d s)$, Reading strategies of first and second language learners: see how they read (pp. 11-24). Nor wood. Unpublished MA: Christopher-Gordon publishers.

Al-Ahmadi, K. \& Koura, A. (2012) The effectiveness of using SQ3R Strategy indeveloping the reading comprehension skills of secondary school students. 31stCDELT National symposim. Ain Shams University.

Alexander, F. (2005) the importance of reading. Scholastic. Retrieved from: $\quad$ www.scholastic.com/schoolage/experts/learning/9-12impofreading.htm on oct.21, 2019

Anderson, N.J. (2003). Scrolling, clicking, and reading English: online reading strategies in a second/foreign language. The reading Matrix, 3 (3), 1-33.

Badrawi, N. (1995): Reading Comprehension. Why, when and it in the EFL Classroom. In: Zahar, Christine (ed): Proceedings of the Second EFL skills conference of Auc, 3rd, 4th December. 
Cooper, J. D., Warnck, E. W. and Shipnsan, D.A. (1988). The what and how of reading instruction. USA: Merril Publishing High Company.

Cooper, J. (1995). Good Readers Are made Not Born. Conference OodCQr (QT - e Books)

Dabbour, K. (2001). A cognitive strategies program in English language to improve reading comprehension for university students. Unpublished MA. thesis. AinShams University.

E-Eskey, D.(1986): Theoretical foundations. In; Dubgin, F., E.Eskey, D. and Grade W. (eds): Teaching second language for academic purpose. California: Addison Wesly publishing Company.

Eskey, D. E. (2005). Reading in a second language. In E. Hinkel (Ed.),Handbook of second language teaching and learning (pp. 563- 580). Mahwah, NJ: Lawrence Erlbaum Associates.

El-Garawany, M. (2010). The effects of repeated reading strategies on developingoral reading fleuncy and reading comprehension among EFL Prospective teachers. Unpublished MA. thesis. Menoufia University.

Farag, M. (2011). The use of the electronic book in developing English reading skills among second year preparatory students. Unpublished MA. thesis. Menoufia University.

Ghoneim, N. (2012). The effectiveness of thinking maps on the preparatory students' development of EFL inferential reading comprehension. Occasional papers in the development of English language Education. Ain Shams University. Vol.54.

Greenall, S. and swan M. (1990). Effective Reading: Reading skills for advanced student. Cambridge University press, New York, Forth printing.

Ibrahim,S. (2007): Training program in learning meta cognitive strategies in English to improve reading comprehension for lowachievers in preparatory school. Unpublished M.A thesis, faculty of Education. Ain Shams university. 
Ismail, A. (1997). A suggested Programme for Developing Some Reading Skills in English among Primary Pupils. M.A. thesis. Zagazig University.

Leane, s (2002). The Basics of teaching Reading skills. The ETJ journal, 3 (1), Retreived from http://www.davidenglishhouse.com/journalpdfs/vol3nol/sections/spri ng2002reading.pdf on 2nd May 2019.

Macmillan English Dictionary (2002). Macmillan publishers LTD, available online URL:http://www.Macmillan.com.mx.retrievedonJune2019

Megria, N. (2010). Effectiveness of using content based instruction in improving reading comprehension skills and scientific concepts among primary school pupils. Unpublished MA. thesis. Menoufia University.

Mokhtari, k., and sheorey, R. (Eds.) (2008). Reading strategies for first and second -language learners. see how they read. Nor wood, Unpublished MA thesis: Christopher - Gordon Publishers.

Serran, G. (2002): Improving Reading Comprehension: A comparative study of Metacognitive strategies. (An online Eric database full text No ED 463550)

Shehata, M. (2006). The effectiveness of semantic mapping and DRTA strategy in developing Benha High Institute of Technology students' reading comprehension skills. M.A. thesis. Benha University.

Sheu, S. (2004). The effects of extensive reading on learners' reading Ability Development. Journal of National Taipei teachers college, vol. 17, No. 2 (sep. 2019) 213 228. retrieved from Academic.ntue.edu.tw/ezfiles/7/1007/img/41/14-2-9.pdf.

Sirisrimangkorn, L \& Suwanthep, K (2013).The Effects of Integrated Drama-Based Role Play and Student Teams Achievement Division (STAD) on Students' Speaking Skills and Affective

Involvement. Scenario. Volume VII. Issue 2. PP37-51. Retrieved from http://research.ucc.ie/scenario/2013/02/SirisrimangkornSuwanthep /05/en. onMarch 15,2020 
Tarim, $K \&$ Akdeniz, F. (2008). The effects of cooperative learning on Turkish elementary students' mathematics achievement and attitude towards mathematics using TAI and STAD methods. Educational Studies in Mathematics. Vol. 67.pp 77-91.

Tawfeek, w. (2009). Effectiveness of the Jigsaw method in developing English reading skills of first year preparatory pupils. Unpublished MA. thesis. Menoufia University.

Thonis, E. W., (1988). Teaching reading to non-English speakers (3rd Ed.). New York:

Ma Cmillan Publishing Company. Warawudhi, R (2012).English Reading Achievement: Student Teams-Achievement Division (STAD) vs. Lecture Method for EFL Learners. JIRSEA 5.Volume 10

Zaza, M. (2001): Developing Metacognitive Strategies and determining their effects on the Academic Reading Skills of Freshman Students of The English Section in Faculties of Education, Zagazig University. 


\section{Appendix 1}

The reading comprehension pre-test; items and their description:

\begin{tabular}{|c|c|c|}
\hline Q. No. & Skills measured & Sub-skills measured \\
\hline $\begin{array}{l}\mathrm{A} \\
\mathrm{C}\end{array}$ & $\begin{array}{l}\text { 1- literal comprehension } \\
\text { skills }\end{array}$ & $\begin{array}{l}\text { 1-a- determining the meaning of } \\
\text { words from context. }\end{array}$ \\
\hline $\mathrm{F} 1$ & $\begin{array}{l}\text { 1- literal comprehension } \\
\text { skills }\end{array}$ & 1-b- recognizing the main idea. \\
\hline $\begin{array}{l}\text { B } \\
D \\
G\end{array}$ & $\begin{array}{l}\text { 1- literal comprehension } \\
\text { skills }\end{array}$ & 1-c- identifying supporting details. \\
\hline $\mathrm{F} 2$ & $\begin{array}{l}\text { 2-critical comprehension } \\
\text { skills }\end{array}$ & $\begin{array}{l}\text { 2-a- recognizing the author's } \\
\text { purpose. }\end{array}$ \\
\hline $\mathrm{E}$ & $\begin{array}{l}2-\quad \text { critical } \\
\text { comprehension skills }\end{array}$ & $\begin{array}{l}\text { 2-b- identifying relationships } \\
\text { between sentences. }\end{array}$ \\
\hline $\mathrm{H}$ & $\begin{array}{l}2-\quad \text { critical } \\
\text { comprehension skills }\end{array}$ & 2-c- drawing logical conclusions \\
\hline
\end{tabular}




\section{Appendix II}

Description of the reading comprehension post-test; items and their description

\begin{tabular}{|c|c|c|}
\hline $\begin{array}{l}\text { Q. } \\
\text { No. }\end{array}$ & Skills measured & Sub-skills measured \\
\hline $\begin{array}{l}\text { A } \\
\text { C }\end{array}$ & $\begin{array}{l}\text { 1- Literal comprehension } \\
\text { skills }\end{array}$ & $\begin{array}{l}1 \text {-a- determining the meaning of } \\
\text { words from context. }\end{array}$ \\
\hline D1 & $\begin{array}{l}\text { 1- Literal comprehension } \\
\text { skills }\end{array}$ & 1-b- recognizing the main idea. \\
\hline $\begin{array}{l}B \\
G\end{array}$ & $\begin{array}{l}\text { 1- Literal comprehension } \\
\text { skills }\end{array}$ & 1-c- identifying supporting details. \\
\hline D2 & $\begin{array}{l}\text { 2- Critical comprehension } \\
\text { skills }\end{array}$ & $\begin{array}{l}\text { 2-a- recognizing the author's } \\
\text { purpose. }\end{array}$ \\
\hline $\begin{array}{l}\mathrm{E} \\
\mathrm{F}\end{array}$ & $\begin{array}{l}\text { 2- Critical comprehension } \\
\text { skills }\end{array}$ & $\begin{array}{l}\text { 2-b- identifying relationships } \\
\text { between sentences. }\end{array}$ \\
\hline $\mathrm{H}$ & $\begin{array}{l}\text { 2- Critical comprehension } \\
\text { skills }\end{array}$ & 2-c- drawing logical conclusions \\
\hline
\end{tabular}

